Articles

Contrasting contrastive approaches Bart Defrancq

On the use of translation corpora in contrastive linguistics: A case study of impersonalization in English and German Volker Gast

Asynchronous grammaticalization: $\mathrm{VI}$-conditionals in presentday English and German Torsten Leuschner and Daan Van den Nest

Morphological contrasts between Modern Greek and Italian: The case of compounding Giannoula Giannoulopoulou

Possessive / bahuvrīhi compounds in German: An analysis based on comparable compounds in Modern Greek Maria Koliopoulou

Expressing the source of dispossession acts in French and Spanish: A contrastive study of voler and robar Renata Enghels and Kim Wylin

A discourse-based approach to some uses of the conjunction que in Romance languages

Teresa M. Rodríguez Ramalle

Reviews

Umberto Ansaldo, Contact languages. Ecology and evolution in Asia. Reviewed by Yaron Matras

Klaus Fischer, Satzstrukturen im Deutschen und Englischen.

Typologie und Textrealisierung Reviewed by Erich Steiner

\title{
LANGUAGES
}

\section{IN CONTRAST}

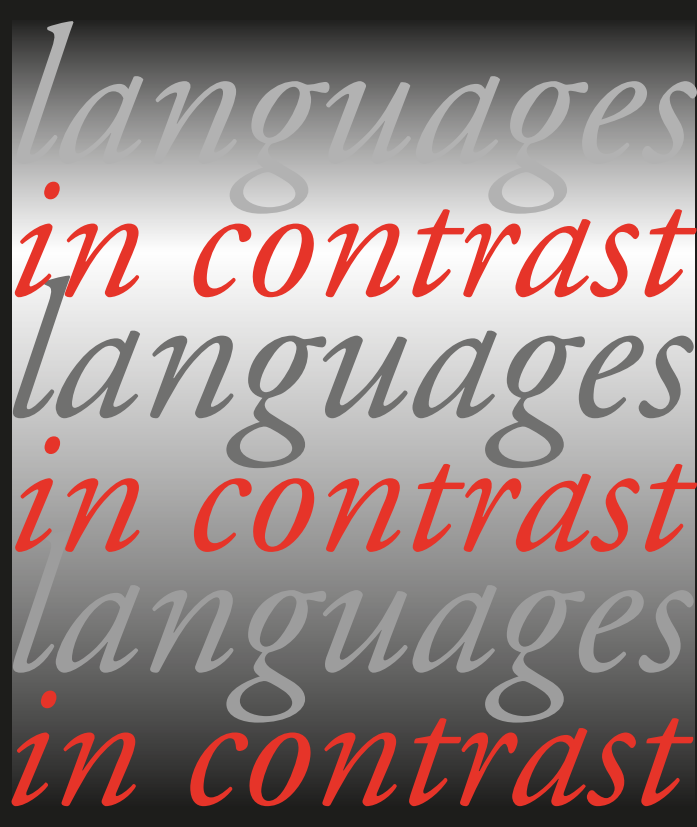

VOLUME 15 ISSUE 1

2015 
Languages in Contrast aims to publish contrastive studies of two or more languages. Any aspect of language may be covered, including vocabulary, phonology, morphology, syntax, semantics, pragmatics, text and discourse, stylistics, sociolinguistics and psycholinguistics.

Languages in Contrast welcomes interdisciplinary studies, particularly those that make links between contrastive linguistics and translation, lexicography, computational linguistics, language teaching, literary and linguistic computing, literary studies and cultural studies.

Languages in Contrast provides a home for contrastive linguistics. It will enable advocates of different theoretical linguistic frameworks to publish in a single publication to the benefit of all involved in contrastive research.

Languages in Contrast provides a forum to explore the theoretical status of the field; stimulates research into a wide range of languages; and helps to give the field of contrastive linguistics a distinct identity.

Language in Contrast is covered in the following indexing and abstracting services:

IBR/IBZ, Linguistic Bibliography/Bibliographie Linguistique, LLBA, European Reference Index

for the Humanities and TSA Online.
LIC Subscription Rate, vol. 15. 2015. (2 issues; ca. 300 pp.)

PRINT + ONLINE EUR 203.00

ONLINE-ONLY EUR 185.00

Individuals may apply for a special subscription rate:

PRINT + ONLINE EUR 70.00

ONLINE-ONLY EUR 65.00

Private subscriptions are for personal use only, and must be pre-paid and ordered directly

from the publisher.

All prices for PRINT + ONLINE include postage/handling.

Subscription orders as well as address changes should be sent to:

John Benjamins Publishing Company, Subscriptions

P.O. Box 36224, 1020 ME AMSTERDAM, The Netherlands

Fax: $+31(20) 6739773$

subscriptions@benjamins.n

www.benjamins.com

\section{Guidelines for Contributors}

LiC invites contributions relevant to the aim and scope of the journal.

Submission instructions and guidelines can be found on the journal's website:

www.benjamins.com/catalog/lic

All correspondence concerning editorial matters - inquiries regarding suitable topics, length of manuscripts, reviews, etc. - should be sent directly to the editors:

Signe Oksefjell Ebeling and Hilde Hasselgård at: languages-in-contrast@ilos.uio.no

Languages in Contrast offers online submission and manuscript tracking:

www.editorialmanager.com/lic

ISSN 1387-6759 / E-ISSN 1569-9897

๑) John Benjamins Publishing Company, Amsterdam/Philadelphia

Photocopying: In the USA: Authorization to photocopy items for internal or personal use is granted by John Benjamins Publishing Company, provided that the appropriate fee is paid directly to the Copyright Clearance Center, 222 Rosewood Drive, Danvers MA 01923, USA. Fees are subject to change.

Fees are subject to change. In the rest of the world: Permission to photocopy must be obtained from the copyright owner. Please apply to: John Benjamins Publishing Company, P.O. Box 36224, 1020 ME Amsterdam. The Netherlands.

All views or conclusions are those of the authors of the articles and not necessarily those of the editorial staff or the publisher. 